\title{
PERJANJIAN IKLAN DI RADIO SUARA AKBAR SURABAYA MENURUT HUKUM ISLAM DAN HUKUM POSITIF
}

\author{
Alifia Nisa Ikbar \\ BTPN Syariah Surabaya \\ alifiasanis@gmail.com
}

\begin{abstract}
The data of this research were collected using observation, interview, and literature study techniques. Then analyzed with descriptive techniques in describing the problem of advertising agreements at Radio Suara Akbar Surabaya. After the data obtained were then analyzed using the Islamic Law and Positive Law. The results of this study concluded that the advertising agreement on SAS FM radio Surabaya with the advertiser, namely the Al Falah Social Fund Foundation (YDSF) had no procedural problems, but in practice there was a default by SAS FM radio with the broadcaster's negligence in managing the time. So that, the advertisement cannot be played as agreed, namely at the exact time of the SAS FM radio signal, in addition to an erratic power outage, and an unexpected time transmitter malfunction. The advertising agreement in this case, according to Islamic law, there are conditions that are not fulfilled, so that it is detrimental to the YDSF advertiser whose advertisement is not shown at the right time signal. According to positive law, it also causes losses to the party carrying out the advertisement. So that, the advertiser can claim compensation for both broadcast time and costs. In this case, the aggrieved party is the client by not showing the advertisement as agreed, then SAS FM is required to change the broadcast time outside the existing agreement.
\end{abstract}

Keywords: Agreement, Default, and Compensation

Abstrak: Data penelitian ini dikumpulkan dengan menggunakan teknik observasi, wawancara, dan studi pustaka. Kemudian dianalisis dengan teknik deskriptif dalam menjabarkan masalah perjanjian iklan di Radio Suara Akbar Surabaya. Setelah data yang didapatkan kemudian dianalisis menggunakan pendekatan Hukum Islam dan Hukum Positif. Hasil penelitian ini menyimpulkan bahwa perjanjian iklan di radio SAS FM Surabaya dengan pengiklan yakni Yayasan Dana Sosial Al Falah (YDSF) secara prosedur tidak ada masalah, namun secara praktik adanya wanprestasi yang dilakukan oleh radio SAS FM dengan adanya kelalaian penyiar dalam mengatur waktu sehingga iklan tersebut tidak dapat diputar sebagaimana kesepakatan, yaitu tepat pada time signal radio SAS FM, selain itu adanya pemadaman listrik yang tidak menentu, serta terjadi rusaknya pemancar waktu yang tidak diduga. Perjanjian Iklan kasus ini menurut hukum Islam terdapat syarat yang tidak dipenuhi sehingga merugikan pihak pengiklan YDSF yang tidak diputar iklannya tepat pada time signal. Menurut hukum positif juga menimbulkan kerugian kepada pihak yang melangsung iklan, sehingga pihak pengiklan dapat menuntut ganti rugi baik waktu siar dan biaya. Dalam kasus ini pihak yang dirugikan adalah client dengan tidak ditayangkan iklan

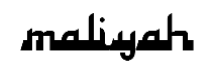

Jurnal Hukum Bisnis Islam

Volume 10, Nomor 02, Desember 2020

p-ISSN: 2088-4869/ e-ISSN: 2597-4351 
Perjanjian Iklan Di Radio Suara Akbar Surabaya Menurut Hukum Islam ...

sebagaimana kesepakatan, maka pihak SAS FM diwajibkan mengganti jam tayang di luar kesepakatan yang sudah ada.

Kata Kunci: Perjanjian, Wanprestasi, Dan Ganti Rugi

\section{Pendahuluan}

Promosi menjadi hal yang wajib bagi perusahaan untuk mepopulerkan produknya. Baik melalui media cetak maupun elektronik seperti televise dan radio. Supaya sebuah promosi iklan dapat berjalan dengan baik, maka perlu dibentuk suatu peraturan mengenai hak dan juga kewajiban para pihak yang menayangkan iklan tersebut dalam sebuah perjanjian, yang dalam praktiknya disebut dengan perjanjian iklan.

Perjanjian iklan tidak diatur secara khusus dalam KUH Perdata, melainkan diatur secara umum dalam pasal $1319 \mathrm{KUH}$ Perdata yang membagi perjanjian secara garis besar ke dalam dua katagori yaitu perjanjian bernama atau nominaat, yaitu perjanjian-perjanjian yang diatur dan diberi nama oleh undang-undang dan perjanjian tidak bernama atau innominaat yaitu perjanjian yang tidak diatur dalam KUHPerdata, namun tumbuh di dalam masyarakat. Lahirnya perjanjian tidak bernama tersebut disesuaikan dengan kebutuhan-kebutuhan dalam praktik pada berbagai macam kehidupan dan tergantung pada para pihak yang membuatnya.

Promosi adalah kegiatan yang ditujukan untuk mempengaruhi konsumen agar mereka dapat menjadi kenal akan produk yang ditawarkan oleh suatu perusahaan, sehingga mereka tertarik akan membeli produk tersebut. Menurut Prof. Basu Swastha dan Irawan dalam bukunya yang berjudul AsasAsas Marketing, promosi adalah arus informasi atau persuasi satu arah untuk mengarahkan seorang atau organisasi terhadap tindakan yang menciptakan pertukaran dalam pemasaran. ${ }^{1}$

\footnotetext{
${ }^{1}$ Swastha.Dkk, Asas-Asas Marketing (Yogyakarta: Liberty, 2005).349
} 
Menurut Kusmono, definisi promosi adalah usaha yang dilakukan pasar untuk mempengaruhi pihak lain agar berpartisipasi dalam kegiatan pertukaran. ${ }^{2}$ Sedangkan menurut Sistaningrum, promosi adalah suatu upaya atau kegiatan perusahaan dalam mempengaruhi konsumen aktual maupun konsumen potensial agar mereka memiliki minat untuk melakukan pembelian terhadap produk yang ditawarkan, saat ini atau di masa yang akan datang. ${ }^{3}$

Adapun alat yang digunakan dalam promosi terdiri dari Periklanan (Advertising), Promosi Penjualan (Sales Promotion) dan Pemasaran Langsung (Direct Marketing). Upaya dalam memasarkan dan memperkenalkan suatu produk kepada masyarakat luas selaku konsumen, salah satu caranya adalah dengan melalui iklan. Sebab, iklan merupakan alat yang efektif dalam memperkenalkan suatu produk kepada masyarakat. Iklan merupakan sarana bagi produsen untuk menarik minat konsumen akan barang atau jasa yang diproduksinya. Bagi pihak konsumen sendiri, iklan merupakan pemberitahuan akan barang yang dibutuhkannya dan konsumen juga dapat menjatuhkan pilihan terhadap barang yang menurut mereka paling baik.

Menurut Kamus Besar Bahasa Indonesia (KBBI), iklan adalah berita atau pesan untuk mendorong, membujuk khalayak ramai agar tertarik pada barang dan jasa yang ditawarkan; pemberitahuan kepada khalayak mengenai barang atau jasa yang dijual, dipasang di dalam media massa (seperti surat kabar dan majalah) atau di tempat umum. Sedangkan pengertian dari promosi penjualan adalah menurut Institute of Sales Promotion in England: Promosi penjualan terdiri dari serangkaian teknik yang digunakaan untuk mencapai sasaran dari penjualan atau pemasaran dengan menggunakan biaya yang efektif, dengan memberikan nilai tambah pada produk atau jasa baik kepada para perantara maupun pemakai

\footnotetext{
${ }^{2}$ Kiswono. Gugup, Pengantar Bisnis, edisi 1, C. (Yogyakarta: BPFE, 2001).374

${ }^{3}$ Sistaningrum, Manajemen Promosi Pemasaran (Jakarta: Index, 2002).98
} 
Perjanjian Iklan Di Radio Suara Akbar Surabaya Menurut Hukum Islam ...

langsung, biasanya tidak dibatasi dalam jangka waktu tertentu. ${ }^{4}$

Menurut Suyanto, pengertian direct marketing atau pemasaran langsung adalah sistem pemasaran yang memakai saluran langsung untuk mencapai konsumen dan menyerahkan barang atau jasa kepada konsumen tanpa adanya perantara. Untuk menghasilkan tanggapan dan atau transaksi yang dapat diukur pada suatu lokasi. ${ }^{5}$ Agar dapat beriklan di media masa, perusahaan harus membuat perjanjian iklan supaya dapat dimuat sebagaimana mestinya. Media masa yang digunakan dalam beriklan bisa berupa koran, televisi, radio, dan media sosial. Perjanjian dalam Kitab Undang-Undang Hukum Perdata (KUH Perdata) pasal 13 adalah perbuatan dengan satu orang atau lebih mengikatkan dirinya terhadap satu orang atau lebih. Dari peristiwa ini, muncul suatu hubungan hukum antara dua orang atau lebih yang disebut Perikatan yang di dalamya terdapat hak dan, kewajiban masing-masing pihak. ${ }^{6}$ Sedangkan dalam hukum Islam, perjanjian disebut dengan akad yang secara etimologi berarti menyimpulkan. ${ }^{7}$ Hal ini diperjelas dalam Q.S An-Nahl: 91 yang artinya: "Dan tepatilah Perjanjian dengan Allah apabila kamu berjanji dan janganlah kamu membatalkan sumpah-sumpah (mu) itu, sesudah meneguhkannya, sedang kamu telah menjadikan Allah sebagai saksimu (terhadap sumpah-sumpahmu itu). Sesungguhnya Allah mengetahui apa yang kamu perbuat."8

Adapun di dalam Q.S Al-Maidah:1 yang artinya: "Hai orang-orang yang beriman, penuhilah aqad-aqad itu. Dihalalkan bagimu binatang ternak, kecuali yang akan

\footnotetext{
4 "Pengertian ,Fungsi Tujuan Promosi," https://dhanialfirdaus.wordpress.com/2008/11/06/definisipengertian-promosifungsitujuan-bauran-promosi-promotional-mix-produk/. Akses tg; 27 Maret 2018 Pukul 07.47 WIB

${ }^{5}$ M Suryanto, Marketing Strategi (Yogyakarta: Andi Publisher, 2007).219

${ }^{6}$ Kitab Undang-Undang Perdata (Jakarta: PT. Pradnya Paramita, n.d.).338

${ }^{7}$ Mahmud Yunus, Kamus Arab Indonesia (Jakarta: PT. Mahmud Yunus, n.d.). 274

${ }^{8}$ Musyaf Aisyah Al-Qur'an Dan Terjemah (Bandung: Jabal, n.d.).227
} 
dibacakan kepadamu. (yang demikian itu) dengan tidak menghalalkan berburu ketika kamu sedang mengerjakan haji. Sesungguhnya Allah menetapkan hukum-hukum menurut yang dikehendaki-Nya." ${ }^{9}$

Adapun syarat sah dalam perjanjian Berdasarkan ketentuan Pasal 1320 Kitab Undang-Undang Hukum Perdata, suatu perjanjian dinyatakan sah apabila telah memenuhi 4 (empat) syarat komulatif. Keempat syarat untuk sahnya perjanjian tersebut antara lain ${ }^{10}$ :

1. Sepakat diantara mereka yang mengikatkan diri. Artinya para pihak yang membuat

2. Perjanjian telah sepakat atau setuju mengenai hal-hal pokok atau materi yang diperjanjikan. Dan kesepakatan itu dianggap tidak ada apabila diberikan karena kekeliruan, kekhilafan, paksaan ataupun penipuan.

3. Kecakapan untuk membuat suatu perikatan. Arti kata kecakapan yang dimaksud dalam hal ini adalah bahwa para pihak telah dinyatakan dewasa oleh hukum, yakni sesuai dengan ketentuan KUH Perdata, mereka yang telah berusia 21 tahun, sudah atau pernah menikah. Cakap juga berarti orang yang sudah dewasa, sehat akal pikiran, dan tidak dilarang oleh suatu peraturan perundang-undangan untuk melakukan suatu perbuatan tertentu. Dan orang-orang yang dianggap tidak cakap untuk melakukan perbuatan hukum yaitu orang-orang yang belum dewasa. Menurut Pasal 1330 KUH Per jo. Pasal 47 UU Nomor 1 tahun 1974 tentang Perkawinan yaitu orang-orang yang ditaruh dibawah pengampuan, menurut Pasal 1330 jo. Pasal 433 KUPerdata; serta orang-orang yang dilarang oleh undang-undang untuk melakukan perbuatan hukum tertentu seperti orang yang telah dinyatakan pailit oleh pengadilan.

4. Suatu hal tertentu. Artinya, dalam membuat perjanjian, apa yang diperjanjikan harus jelas sehingga hak dan kewajiban para pihak bisa ditetapkan.

\footnotetext{
${ }^{9}$ Ibid.106

${ }^{10}$ Kitab Undang-Undang Perdata.339
} 
5. Suatu sebab yang halal. Artinya, suatu perjanjian harus berdasarkan sebab yang halal yang tidak bertentangan dengan ketentuan Pasal 1337 KUH Perdata, yaitu :

a. Tidak bertentangan dengan ketertiban umum

b. Tidak bertentangan dengan kesusilaan; dan

c. Tidak bertentangan dengan undang-undang.

Sebagaimana yang telah dijelaskan diatas, syarat kesatu dan kedua dinamakan syarat subjektif, karena berbicara mengenai subjek yang mengadakan perjanjian, sedangkan ketiga dan keempat dinamakan syarat objektif, karena berbicara mengenai objek yang diperjanjikan dalam sebuah perjanjian. Dalam perjanjian bilamana syarat-syarat subjektif tidak terpenuhi maka perjanjiannya dapat dibatalkan oleh hakim atas permintaan pihak yang tidak cakap atau yang memberikan kesepakatan secara tidak bebas. Selama tidak dibatalkan, perjanjian tersebut tetap mengikat. Sedangkan, bilamana syarat-syarat objektif yang tidak dipenuhi maka perjanjiannya batal demi hukum. Artinya batal demi hukum bahwa, dari semula dianggap tidak pernah ada perjanjian sehingga tidak ada dasar untuk saling menuntut di pengadilan.

Dengan demikian, dari pemaparan di atas penulis ingin lebih mendalami tentang Analisis Hukum Islam dan Hukum Positif Terhadap Perjanjian Iklan di Radio SAS FM Surabaya, sebab penulis menemukan suatu kejanggalan ten.tang perjanjian iklan yang telah disepakakati melalui MoU, namun terdapat kelalaian di dalamnya.

Penelitian ini merupakan penelitian lapangan (field reseach) yang memfokuskan pada kasus yang terjadi di lapangan (Radio SAS FM Surabaya) dengan tetap merujuk pada konsep-konsep yang ada. Penulis mengambil penelitian ini, dikarenakan penulis menemukan sesuatu hal tentang praktik perjanjian yang tidak sesuai dengan teori hukum Islam juga hukum Positif. Adapun objek dari penelitian penulis adalah orang, perusahaan, surat perjanjian atau MoU (Memorandum of Understanding). Adapun sumber data yang penulis peroleh, yaitu melalui sumber primer dan sumber sekunder; 
Sumber data utama yang didapatkan peneliti dari hasil wawancara dengan pihak-pihak yang terkait dalam proses pelaksanaan perjanjian iklan di Radio SAS FM seperti, manager, staf admin, dan crew lainnya. Karena penelitian ini merupakan penelitian yang tidak terlepas dari kajian hukum Islam dan hukum positif maka penulis menempatkan sekunder data yang berkenaan dengan kajian-kajian tersebut sebagai sumber data sekunder. Adapun buku-buku atau literatur yang menjadi sumber data sekunder. Data yang sudah terkumpul kemudian diolah. Pengolahan data umumnya seperti; Organizing, Editing, Analyzing

\section{Perjanjian Dalam Hukum Islam Dan Hukum Positif}

Perjanjian dalam hukum Islam, sering disebut dengan akad. Kata akad berasal dari kata al-'aqd, yang berarti mengikat, menyambung atau menghubungkan. ${ }^{11}$ Akad atau kontrak berasal dari bahasa Arab yang berarti ikatan atau simpulan baik ikatan yang nampak (hissyy) maupun tidak nampak (ma'nawy).12 Pengertian akad menurut bahasa berasal dari kata al-Aqd, bentuk masdar adalah kata 'Aqada dan jamaknya adalah al-Uqud yang berarti perjanjian (yang tercatat) atau kontrak. ${ }^{13}$ Akad atau perjanjian atau kesepakatan atau transaksi dapat diartikan sebagai komitmen yang terbingkai dengan nilai-nilai syariah.

Secara terminologi fiqh,akad didefinisikan dengan pertalian ijab (pernyataan melakukan ikatan) dan kabul (pernyataan penerimaan ikatan) sesuai dengan kehendak syariat yang berpengaruh kepada objek perikatan. Pencantuman kata-kata yang sesuai dengan kehendak syariat maksudnya bahwa seluruh perikatan yang dilakukan oleh dua pihak atau lebih tidak dianggap sah apabila tidak sejalan

\footnotetext{
${ }^{11}$ Syamsul Anwar, Hukum Perjanjian Syariah (Jakarta: Rajawali Pers, 2010).97

${ }^{12}$ Fayruz Abadyy Majd al-Din Muhammad Ibn Ya'qub, Al-Qamus Al-Muhit, Jilid 1. (Beirut: D Jayl, n.d.). 327

13 A.W Munawwir, Kamus Al-Munawwir Arab-Indonesia Lengkap (Surabaya: Pustaka Progressif, 1997).953
} 
dengan kehendak syara'. Misalnya, kesepakatan untuk melakukan riba, menipu orang lain atau merampok kekayaan orang lain. Adapun pencantuman kata-kata "berpengaruh pada objek perikatan", maksudnya adalah terjadinya perpindahan pemilikan dari satu pihak (yang melakukan ijab) kepada pihak yang lain (yang menyatakan qabul).

Dalam istilah fikih, secara umum akad berarti sesuatu yang menjadi tekad seseorang untuk melaksanakan, baik yang muncul dari satu pihak, seperti wakaf, talak, dan sumpah, maupun yang muncul dari dua pihak, seperti jual beli, sewa, wakalah, dan gadai. ${ }^{14}$ Secara khusus akad berarti perikatan yang ditetapkan dengan ijab qabul berdasarkan ketentuan syara' yang berdampak pada objeknya. Dalam akad biasanya dititikberatkan pada kesepakatan antara dua belah pihak yang ditandai dengan ijab qabul.

Menurut Hasbi Ash-Shiddieqy, yang mengutip definisi yang dikemukakan Al-Sanhury, akad berarti perikatan ijab dan qabul yang dibenarkan syara' yang menetapkan kerelaan kedua belah pihak. ${ }^{15}$ Adapun Jama' Al-Uquud, memiliki arti tersendiri mengenai perjanjian, yakni;

1. Mengikat atau Al-Rabit

2. Sambungan atau Al-Aqd'

Dari pemaparan di atas dapat disimpulkan bahwa pengertian akad mencakup: ${ }^{16}$ Pertama Perjanjian atau Al-Aqd. Kedua Persetujuan dua orang atau lebih. Ketiga Perikatan atau Al-Aqd. Akad merupakan sebuah perikatan antara ijab dan qabul dengancara yang dibenarkan syara' yang menetapkan adanya akibat-akibat hukum pada objeknya. Dalam istilah lain, Ahmad Azhar Basir mendefinisikan akada sebagai berikut: ${ }^{17}$

\footnotetext{
${ }^{14}$ Ascarya, Akad Dan Produk Bank Syariah (Jakarta: RajaGrafindo Persada, 2011).35

${ }^{15}$ Gemala Dewi, Aspek-Aspek Hukum Dan Perasuransian Syari'ah Di Indonesia (Jakarta: Kencana Cet ke-4, 2007).11

${ }^{16}$ Qomarul Huda, Fiqh Muamalah (Yogyakarta: Teras, 2011).26

${ }^{17}$ Ahmad Azar Basyir, Asas-Asas Hukum Muamalat (Yogyakarta: Universitas Islam Indonesia Press, 2000).65
} 
Suatu perikatan antara ijab dan qabul dengancara yang dibenarkan syara' yang menetapkan adanya akibat-akibat hukum pada objeknya. Ijab adalah pernyataan pihak pertama mengenai isi perikatan yang diinginkan sedang qabul adalah pernyataan pihak kedua untuk menerimanya.

Abdul Aziz Muhammad Azzam berkata: ,setia suatu hal yang diikatkan oleh seseorang terhadap suatu urusan yang hendak dilaksanakan secara wajib, atau diikatkan kepada orang lain untuk dilaksanakan secara wajib, maka maksudnya adalah iltizam (mengharuskan) untuk menunaikan janji yang telah disepakati oleh kedua belah pihak. ${ }^{18}$

Adapun yang menjadi sumber utama iltizam adalah:

1. Akad yaitu kehendak kedua belah pihak untuk melakukan sebuah perikatan.

2. Kehendak sepihak, yaitu keinginan sendiri untuk melakukan sesuatu.

3. Perbuatan yang bermanfaat, seperti menolong orang yang membutuhkan pertolongan.

4. Perbuatan yang merugikan, seperti ketika merusak barang milik orang lain, yang merusak wajib mengganti barang tersebut. ${ }^{19}$

\section{Syarat dan Rukun Perjanjian menurut Hukum Islam}

Dalam hukum islam terbentuknya sebuah akad (perjanjian) yang sah dan mengikat haruslah dipenuhi rukun dan syarat akad. Syarat akad terdiri dari empat macam yakni:

1. Syarat Terbentuknya Akad (syuruth Al-In'iqad). Syarat tejadinya akad yaitu terbagi kepada syaat umum dan syarat khusus, yang termasuk syarat umum adalah rukun yang harus ada dalam melakukan akad seperti: orang yang berakad, objek akad, objek tersebut bermanfaat, dan tidak dilarang oleh ketentuan syara'.

2. Syarat Keabsaahan Akad (Syuruth Ash-Shihah)

\footnotetext{
${ }^{18}$ Abdullah Aziz Muhammad Azzam, Fiqh Muamalat (Jakarta: Sinar Grafika Offset, 2010).16

${ }^{19}$ Gemala. Dkk Dewi, Hukum Perikatan Islam Di Indonesia, n.d.87
} 
Menurut ulama' Hanafi, yang telah dikutip oleh Prof. Dr. fathurrahman Djamil, bahwa syarat sahnya akad apabila terhindar dari lima hal yakni: pertama Al-jahalah (ketidak jelasan tentang harga, jenis dan spesifikasi, waktu pembayaran atau lamanya opsi dan penanggung jawab). Kedua Al-Ikhah (keterpaksaan). Ketiga Attauqid (pembatasan waktu). Keempat Al-Gharar (ada unsur kemahdorotan). Kelima Al-Syarthu Al-Fasad (syarat-syarat rusak, seperti pemberian syarat terhadap pembeli untuk mejual Kembali barang yang dibelinya kepada penjual lain dengan harga yang lebih murah).

3. Syarat berlakunya akibat hukum (Syuruthan-Nafadz)

Syarat ini berlangsungnya akad tidak tergantung pada izin orang lain. Syarat berlakuny akad yaitu dengan adanya kepemilikan terhadap barang atau adanya otoritas untuk mengadakan akad, baik secara langsung atau perwakilan dan barang atau jasa tersebut tidak dapat campur tangan dari hak orang lain.

4. Syarat mengikatnya akad (Syurut Al-Luzum)

Suatu akad baru mempunyai kkuatan mengikat apabila terbebs dari segala macam hak Khiyar. Khiyar adalah hak pilih bagi penjual dan pembeli untuk melanjutkan atau membatalkan akad jual beli yang telah dilakukan.

Para ulama menyatakan suatu perjanjian atau akad apabila (1) Berakhirnya masa berlaku akad tersebut apabila akad tersebut memiliki tenggang waktu. (2) Dibatalkan oleh pihak-pihak yang berakad apabila sifatnya tidak mengikat. (3) Dalam akad yang bersifat mengikat dapat berakhir apabila terjadi unsur fasar seperti penipuan ataupun syarat-syarat tidak terpenuhi, belakunya khiyar, akad tidak dilaksanakan oleh salah satu pihak. ${ }^{20}$

\section{Macam-Macam Perjanjian dalam Hukum Positif}

Suatu perikatan merupakan hal yang saling berhubungan dengan hukum antar dua pihak berdasarkan

\footnotetext{
${ }^{20}$ Nasrun Harun, Fiqh Muamalat (Jakarta: Gaya Media Pratama, 2000).108-109
} 
pihak yang satu dengan pihak yang lain, dan pihak yang lain berkewajiban untuk untuk memenuhi tuntutan tersebut. Apabila masing-masing pihak hanya ada satu orang, dan yang dituntut hanya berupa satu hal, dan penuntut ini dapat dilakukan seketika, maka perikatan ini merupakan bentuk perikatan bersahaja atau perikatan murni. Berikut macammacam dari perjanjian yakni:

1. Perjanjian Timbal Balik. Perjanjian timbal balik adalah perjanjian yang menimbulkan kewajiban pokok bagi kedua belah pihak. Misalnya perjanjian jual beli.

2. Perjanjian Cuma-Cuma. Perjanjian ini disebut Cuma-Cuma karena perjanjian ini memberikan keuntungan yang sangat besar bagi salah satupihak saja. Misalnya hibah.

3. Perjanjian Atas Beban. Dimana perjanjian ini prestasi dari pihak yang satu merupakan kontra prestasi dari pihak yang lain, dan antara kedua prestasi itu ada hubungannya menurut hukum.

4. Perjanjian Bernama (Benoemd). Perjanjian yang bernama (khusus) yakni perjanjian yang mempunyai istilah julukansendiri. Perjanjian tersebu diatur dan diberi nama oleh pembentuk undang-undnag berdasarkan tipe yang paling banyak terjadi sehari-hari. Perjanjian ini diatur dalam Bab V sampai dengan Bab XVIII KUH Perdata.

5. Perjanjian Tidak Bernama (Onbenoemd Overeenkomst). Yakni perjanjian yang tidak diatur dalam KUH Perdata, akan tetapi terdapat dalam masyarakat. Perjanjian ini seperti perjanjian pemasaran, perjanjian kerja sama. Di dalam praktiknya, perjanjian ini lahir berdasarkan asas kebebasan berkontrak mengadakan perjanjian.

6. Perjanjian Obligator. Perjanjian obligator banyak para pihak yang sepakat mengikatkan diri untyuk melakukannya penyerahan suatu benda kepada pihak lain. (perjanjian yang menimbulkan perikatan).

7. Perjanjian Kebendaan. Perjanjian kebendaan adalah yang mana perjanjian seseorang yang menyerahkan haknya atas sesuatu benda kepada pihak lain, yang membebankan 
kewajiban pihak itu untuk menyerahkan benda tersebut kepada pihak lain.

8. Perjanjian Konsensual. Perjanjian ini terjad antar dua belah pihak yang mencapai persesuaian kehendak untuk mengadakan perikatan.

9. Perjanjian Riil. Di dalam KUH Perdata ada juga perjanjian yang hanya berlaku sesudah terjadi penyerahan barang. Perjanjian ini dinamakan perjanjian riil. Misalnya perjanjian penitipan barang, pinjam pakai.

10. Perjanjian Liberatoir. Yakni perjanjian dimana para pihak membebaskan diri dari kewaajiban yang ada. Misalnya perjanjian pembebasan hutang.

11. Perjanjian Pembuktian. Yakni perjanjian yang para pihak menentukan pembuktian apakah yang berlaku diantara mereka.

12. Perjanjian Untung-Untungan. Perjanjian untung-untungan adalah perjanjian yang objeknya ditentukan kemudian. Misalnya perjanjian asuransi.

13. Perjanjian Publik. Perjanjian yang sebagian atau seluruh dikuasai oleh hukum publik, karena salah satu pihak yang bertindak adalah pemerintah dan pihak lainnya adalah swasta. Misalnya perjanjian ikatan dinas dan pengadaan barang pemerintah.

14. Perjanjian Campuran. Perjanjian campuran adalah perjanjian yang mengandung berbagai unsur perjanjian. Misalnya pemilik hotel yang menyewakan kamar (sewamenyewa) tetapi menyajikan pula makanan (jual beli) dan juga memberikan pelayanan.

Perjanjian dalam Hukum Positif berasal dari bahasa inggris yaitu contracs, sedangkan dalam bahasa belanda disebut dengan overeenkomst. Suatu perjanjian adalah sematamata untuk suatu persetujuan yang diakui oleh hukum. Persetujuan tersebut merupakan kepentingan yang pokok dalam dunia usaha dan menjadi dasar bagi kebanyakan transaksi dagang seperti jual beli barang, tanah, pembelian kredit, asuransi, pengangkutan barang, pembentukan 
organisasi usaha dan termasuk juga menyangkut tenaga kerja. $^{21}$

Perjanjian atau perikatan secara etimologi adalah ikatan. Sedangkan menurut terminology adalah suatu perbuatan dimana seseorng mengikatkan dirinya kepala seseorang ataupun beberapa orang lain. ${ }^{22}$ Adapun menurut Abdulkadir Muhammad, perjanjian adalah suatu persetujuan dengan dua orang atau lebih saling mengikatkan diri untuk melaksanakan sesuatu hal dalam lapangan harta kekayaan. ${ }^{23}$

Perjanjian dalam Kitab Undang-Undang Hukum Perdata -KUHAPer- masuk dalam buku III, yang memiliki pengertian dalam pasal 1313 KUHPer yaitu perbuatan dengan mana satu orang atau lebih mengikatkan dirinya terhadap satu orang lain atau lebih. Dari peristiwa ini, timbulah suatu hubungan hukum antara dua orang atau lebih yang disebut perikatan yang di dalamya terdapat hak dan kewajiban masing-masing pihak.

\section{Asas-Asas Perjanjian Hukum Positif}

Kitab Undang-Undang Hukum Perdata merumuskan ada lima azas dalam hukum perjanjian:

1. Azas Kebebasan (Freedom of Contract) Azas kebebasan dalam hukum perjanjian memandang bahwa setiap pihak bebas untuk menentukan apakah mereka akan membuat perjanjian atau tidak, bebas mengadakan perjanjian dengan siapa pun, bebas menentukan isi perjanjian, cara pelaksanaan, serta syarat-syarat perjanjian, dan bebas menentukan bentuk perjanjian, apakah lisan atau tertulis.

Azas tersebut telah ada sejak zaman Yunani dan mengalami perkembangan pada zaman Pertengahan (Rennaisance) dengan latar belakang paham individualisme yang memandang bahwa setiap orang bebas memperoleh apa saja yang dia kehendaki. Pelopor paham ini adalah Hugo de

${ }^{21}$ Abdul Kadir Muhammad, Hukum Perjanjian (Bandung: Alumni, 1980).93

22 Titik Triwulan Tutik, Hukum Perdata Dalam Sistem Hukum Nasional (Jakarta: Kencana, 2008).221

${ }^{23}$ Abdul Kadir Muhammad, Hukum Perikatan (Bandung: Bina Cipta, 1982).78 
Grecht, Thomas Hobbes, John Locke, dan J.J. Rousseau. Pasal 1338 ayat (1) KUHP memuat ketentuan mengenai azas kebebasan bahwa: "Semua perjanjian yang dibuat secara sah berlaku sebagai undang-undang bagi mereka yang membuatnya."

2. Azas Konsensualisme (Concensualism) Azas ini memandang bahwa sebuah perjanjian disebut sah apabila ada kesepakatan, yakni persesuaian antara kehendak dan pernyataan yang dibuat oleh kedua belah pihak. Azas ini termaktub dalam pasal 1320 ayat (1) KUHP, berkaitan dengan bentuk perjanjian. Azas ini lahir dari hukum Romawi dan Jerman. Hukum Romawi mengenal azas contractus verbis literis dan contractus innominat, sebuah perjanjian dianggap terjadi apabila memenuhi suatu bentuk yang ditetapkan. Sementara hukum Jerman, mengenal istilah perjanjian riil dan perjanjian formal. Disebut perjanjian riil apabila perjanjian tersebut dibuat dan dilaksanakan secara kontan dan disebut perjanjian formal apabila perjanjian tersebut dalam bentuk tertulis.

3. Azas Kepastian Hukum (Pacta Sunt Servanda) Asas ini memandang bahwa suatu perjanjian memiliki kepastian hukum berkaitan dengan akibat dari perjanjian tersebut, pihak ketiga (hakim, dll.) harus menghormati substansi perjanjian dan tidak boleh melakukan intervensi. Azas kepastian hukum tersebut termaktub dalam pasal 1338 ayat (1) KUHP.

4. Azas Itikad Baik (Good Faith) Azas ini memandang bahwa pelaksanaan substansi perjanjian antara kedua belah pihak didasarkan pada kepercayaan dan itikad baik. Itikad baik tersebut dibedakan menjadi dua, yaitu nisbi dan mutlak. Itikad baik nisbi berkaitan dengan sikap dan tingkah laku subjek perjanjian secara nyata, sedangkan itikad baik mutlak memandang bahwa penilaian itikad baik menyangkut ukuran objektif dan tidak memihak berdasarkan norma-norma yang ada. Azas ini termaktub dalam pasal 1338 ayat (3) KUHP. 
5. Azas Kepribadian (Personality) Azas ini memandang bahwa setiap pihak yang melakukan perjanjian berdasarkan kepentingan diri sendiri. Sebagaimana termaktub dalam pasal 1315 KUHP yang berbunyi: "Pada umumnya seseorang tidak dapat mengadakan perikatan atau perjanjian selain untuk dirinya sendiri," dan ditegaskan dalam pasal 1340: "Perjanjian hanya berlaku antara pihak yang membuatnya." Dengan demikian, sebuah perjanjian hanya mengikat kedua belah pihak. Kecuali, ada kasus khusus sebagaimana disebutkan dalam pasal 1317 KUHP: "Dapat pula perjanjian diadakan untuk kepentingan pihak ketiga, bila suatu perjanjian yang dibuat untuk diri sendiri atau suatu pemberian kepada orang lain, mengandung suatu syarat semacam itu."

Adapun syarat perjanjian yang sah menurut pasal 1320 KUHPerdata yaitu:

1. Adanya kesepakatam antara mereka yang mengikatkan diri, dalam hal ini yang mengikatkan diri adalah pihak radio SAS FM dan pihak client.

2. Cakap untuk membuat suatu perikatan. Maksudnya adalah dari segi umur telah memenuhi syarat, yaitu lebih dari 21 tahun, dalam hal ini kedua belah pihak telah dinyatakan cakap.

3. Adanya suatu sebab, yaitu telah ada kesepakatan dalam penayangan iklan.

4. Adanya sebab yang dihalalkan, yaitu tidak melanggar ketentuan hukum yang berlaku.

Dari pemaparan di atas sudah jelas mengenai syarat yang harus ada di dalam perjanjian serta harus dipenuhi dengan kedua belah pihak. Apabila syarat-syarat di atas tidak dipenuhi oleh kedua belah pihak, maka yang terjadi adalah batal demi hukum menurut pasal 1320 KUH Perdata. Apabila salah satu diantara orang yng mengikat dirinya dalam perjanjian tidak memenuhi isi di dalam perjanjian tersebut maka bisa dikatakan telah melakukan wasprestasi atau ingkar janji. 
Sedangkan menurut R. Setiawan, rumusan di atas selain tidak lengkap juga masih sangat luas. Tidak lengkapnya rumusan tersebut sebab hanya menyebutkan persetujuan sepihak saja, kemudian sangat luas sebab menggunakan perkataan "perbuatan" tercakup juga perwakilan sukarela dan pebuatan melawan hukum. Sehubungan dengan itu maka perlu adanya perbaikan mengenai definisi tersebut, yaitu: ${ }^{24}$

1. Perbutan harus diartikan sebagai perbuatan melawan hukum, yaitu perbutan yang bertujuan untuk menimbulkan akibat hukum.

2. Menambahkan perkataan "atau saling mengikatkan dirinya" dalam pasal 1313 KUH Perdata. Sehingga perumusannya menjadi: "Persetujuan adalah suatu perbuatan hukum, dimana satu orang atau lebih mengikatkan dirinya atau saling mengikatkan dirinya terhadap satu orang atau lebih. ${ }^{25}$

Selanjutnya, pengertian perjanjian ditemukan dalam rerensi lain, yaitu menurut Subekti, perjanjian adalah suatu peristiwa dimana seseorang berjanji kepada seseorang lain atau dimana dua orang itu saling berjanji untuk melaksanakan suatuhal. 26

Dalam kasus ini, Mou antara radio SAS FM dan juga pihak yang beriklan yaitu YDSF adalah diputarnya iklan YDSF pada setiap time signal misal pukul 13.00, 14.00, 15.00, dsb, namun pihak SAS FM kerap kali tidak tepat waktu untuk memutar iklan tersebut, yang disebabkan adanya kelalaian penyiar dalam memanagement waktu, pemadaman listrik, rusaknya pemancar dan lain sebagainya. Jika dianalisa melalui hukum Positif, dampak dari adanya wanprestasi, pihak radio SAS FM harus melakukan yang namanya ganti rugi. Ganti rugi dapat berupa penggantian biaya, penggantian kerugian, ataupun bunga.

\footnotetext{
${ }^{24}$ Johannes Ibrahin, Kartu Kredit Dilematis Antara Kontrak Dan Kejahatan (Bandung: PT Refika Aditama, 2004).29

${ }^{25}$ Ibid. 30

${ }^{26}$ Subekti, Hukum Perjanjian (Jakarta: Intermesa cet ke-12, 1990).1
} 


\section{Wanprestasi}

Wanprestasi adalah pelaksanaan kewajiban yang tidak dipenuhi atau ingkar janji atau kelalaian yang dilakukan oleh debitur, baik karena tidak melaksanakan apa yang telah diperjanjikan dan melakukan sesuatu yang menurut perjanjian tidak boleh dilakukan. Istilah wanprestasi berasal dari bahas Belanda, yaitu wanprestatie yang artinya tidak dipenuhinya prestasi atau kewajiban yang telah ditetapkan terhadap pihakpihak tertentu dalam suatu perikatan baik perikatan yang dilahirkan dari suatu perjanjian atau perikatan yang timbul karena undang-undang. Wanprestasi memberikan akibat hukum terhadap pihak yang melakukannya dan membeawa konsekuensi terhadap timbulnya hak para pihak yang dirugikan untuk menuntut pihak yang melakukan wanprestasi untuk memberikan ganti rugi. Maka dalam hukum diharapkan agar tidak ada salah satu pihak yang merasa dirugikan karena hal wanprestasi tersebut.

Adapun syarat yang harus dipenuhi oleh debitur sehingga dikatakan dalam keadaan wanprestasi, yakni:

1. Syarat materiil, yakni adanya kesengajaan berupa: kesengajaan dan kelalaian. Kesengajaan adalah suatu hal ayang dilakukan seseorang dengan di kehendaki dan diketahui yang didasari oleh pelaku sehingga dapat menimbulkan kerugian pada pihak lain. Sedangkan kelalaian adalah seseorang yang wajib berprestasi seharusnya tahu atau patut menduga bahwa dengan perbuatan atau sikap yang diambil olehnya akan menimbulkan kerugian.

2. Syarat Formil, yakni adanya peringatan atau somasi hal kelalaian ataupun wanprestasi pada pihak debitur harus dinyatakan dahulu secara resmi, dengancara memperingatkan debitur, bahwa kreditor menghendaki pembayaran seketika atau dalam jangka waktu yang pendek. Sedangkan somasi adalah teguran keras secara tertulis dari kreditor berupa akta kepada debitur, supaya debitur harus berprestasi dan disertai dengan sangsi denda 
atau hukuman yang akan dijatuhkan dan diterapkan apabila debitur melakukan wanprestasi atau lalai.

Adanya kelalaian pada debitur membuat kerugian pihak. Kerugian itu dapat dipersalahkan kepada debitur jika ada unsur kesengajaan atau kelalaian dalam peristiwa yang merugidiangkan pada debitur yang dapat dipertanggungjawabkan. Sehubungan dengan kelalaian yang dilakukan oleh debitur, perlu diketahui kewajiban yang dianggap lalai apabila tidak dilaksanakan oleh seorang debitur. Ada beberapa hal yang mengenai wajib dilakukan ketika debitur lalai seperti dibawah ini:

1. Kewajiban untuk memberikan sesuatu yang telah dijanjikan.

2. Kewajiban untuk melakukan suatu perbuatan.

3. Kewajiban ungtuk tidak melaksanakan suatu perbuatan.

Akibat hukum wanprestasi, adalah hukuman atau sangsi yang diberikan kepada debitur karena melakukan wanprestasi. Ada 3 akibat hukum setelah melakukan wanprestasi, yakni:

1. kewajiban membayar ganti rugi, ganti rugi adalah membayar segala kerugian karena musnahnya atau rusaknya barang yang dimiliki kreditur akibat kelalaian dari debitur. Untuk dapat menunyut ganti rugi harus ada penagihan atau somasi terlebih dahulu, kecuali dalam peristiwa tertentu yang tidak memerlukannya teguran. Ketentuan tentang ganti rugi diatur dalam pasal 1246 KUHPerdata yang terdiri dari tiga macam, yaitu: biaya, rugi, dan bunga. Biaya adalah segala pengeluaran yang telah dikeluarkan oleh kreditur, sedangkan bunga adalah segala kerugian yang berupa kehilangan keuntungan yang sudah dibayangkan atau yang sudah diperhitungkan sebelumnya. Ganti rugi harus dihitung berdasarkan nilai uang dan harus berbentuk uang. Maka ganti rugi yang ditimbulkan karena adanya wanprestasi harus bisa diperhitungkan berdasarkan sejumlah uang. Hal ini dimaksudkan supaya terhindar dari terjadinya kesulitan dalam penilaian jika harus ganti dengan cara yang lain. 
2. Pembatalan perjanjian. Sebagai sangsi yang kedua akibat kelalaian seorang debitur yakni berupa pembatalan perjanjian. Sangsi atau hukuman ini, apabila seseorangb tidak dapat melihat sifat pembatalannya tersebut sebagai suatu hukuman. Maka debitur dianggap merasa puas atas segala pembatalan tersebut karena telah merasa dibebaskan dari segala kewajiban supaya dapat melakukan prestasi. Menurut KUH Perdata pasal 1266: syarat batal dianggap selalu dicantumkan bpersetujuan yang memiliki hubungan timbal balik, manakala salah satu pihak tidak memenuhi kewajibannya. Pada hal demikian persetujuan tidak batal demi hukum, akan tetapi pembatalan harus dimintakan kepada hakim. Permintaan ini juga harus dilakukan meskipun syarat batal mengenai tidak dipenuhinya kewajiban yang dinyatakan dalam perjanjian. Jika syaratnya batal tidak dinyatakan dalam persetujuan hakim adalah leluasa untuk menurut keadaan atas permintaan pihak tergugat, dalam memberikan jangka waktu supaya dapat memenuhi kewajibannya maka tidak boleh lebih dari satu bulan.

3. Peralihan resiko. Akibat dari wanprestasi yang berupa peralihan risiko ini berlaku pada perjanjian pembiayaan leasing. Pada hal ini seperti yang terdapat pada pasal 1237 KUH Perdata ayat 2 yang menyatakan bahwa, "jika pihak yang berutang lalai akan menyerahkannya, maka semenjak saat kelalaianya kebendaan adalah atas tanggungannya."

Cederanya akad adalah yang merusak terjadinya akad atau perjanjian karena tidak terpenuhi syarat atau unsur yang Sali akad ng meridhai antara pihak yang melakukan perjanjian. Sahnya suatu akad atau perjanjian apabila telah memenuhi syarat yang tercantum pada pasal 1320 diantaranya; kecakapan, kata sepakat, objek perjanjian, dan kuasa yang halal. Apabila dalan atm melakukan perjanjian semua syarat tersebut telah terpenuhi maka hukumnya sah karena telah sesuai dengan aturan undang-undang. Sedangkan dalam hukum islam tidak jauh berbeda dengan aturan yang ada dalam undang-undang pasal 1320 tersebut. Apabila syarat 
kesepakatan tersebut tidak terpenuhi maka akibat yang timbul adalah perjanjian tersebut yang cedera atau rusak bahkan bisa batal. Adapun hal-hal yang menyebabkan timbulnya kecacatan dalam perjanjian adalah: paksaan (dwaag), kekhilafan (awalig), penipuan (bedrog), dan penyalah gunaan keadaan atau pengaruh tidak pantas (undue influence). Sementara timbulnya kecacatan dalam hukum islam adalah paksaan (al-ikhrahi), penipuan (at-tadlis at-takriri), kekhilafan (al-ghalad atau alkhotok) dan tipu muslihat (al-ghobnu).

\section{Konsekuensi Terjadinya Wanprestasi menurut Hukum Islam}

Dalam penjelasan diatas dijelaskan mengenai perjanjian yang tertulis dalam Q.S An-Nahl: 91 Artinya: Dan tepatilah perjanjian dengan Allah apabila kamu berjanji dan janganlah kamu membatalkan sumpah-sumpah (mu) itu, sesudah meneguhkannya, sedang kamu telah menjadikan Allah sebagai saksimu (terhadap sumpah-sumpahmu itu). Sesungguhnya Allah mengetahui yang kamu perbuat. Yang mana perjanjian itu harus ditepati. Apabila dalam konteks ini perjanjian tidak ditepati maka disebut dengan wanprestasi. Wanprestasi adalah keadaan dimana debitur tidak memenuhi kewajiban prestasinya dalam perjanjian atau tidak memenuhi sebagaimana semestinya atau menurut selayaknya.

Abdul Kadir Muhammad dalam bukunya menyatakan bahwa wanprestasi adalah tidak memenuhi kewajiban yang harus ditetapkan dalam perikatan, baik perikatan yang timbul karena perjanjian maupun perikatan yang timbul karena Undang-Undang. ${ }^{27}$ Jika suatu perjanjian terdapat wanprestasi, maka dalam hukum Islam mengenal adanya ganti rugi atau dikenal dengan istilah dhaman. Dalam menetapkan ganti rugi unsur-unsur yang paling penting adalah dharar atau kerugian pada subyeknya. Dharar dapat terjadi pada fisik, harta atau barang, jasa dan juga kerusakan yang bersifat moral dan perasaan atau disebut dengan dharar adabi termasuk

${ }^{27}$ Muhammad, Hukum Perikatan.20 
didalamnya pencemaran nama baik. Tolak ukur ganti rugi baik kualitas maupun kuantitas sepadan dengan dharar yang diderita pihak korban, walaupun dalam kasus-kasus tertentu pelipatgandaan ganti rugi dapat dilakukan sesuai dengan kondisi pelaku. ${ }^{28}$

Konsep ganti rugi dalam Islam, sebagaimana firman Allah SWT dalam Q.S Al-Isra': 36 yang artinya "Dan jangan kamu mengikuti sesuatu yang tidak kamu ketahui. Karena pendengaran, pengelihatan, dan hati nurani semua itu akan dimintai pertanggung jawaban. ${ }^{29}$ Ayat tersebut menjelaskan bahwa segala sesuatu yang kita lakukan maka akan dimintai pertanggung jawaban oleh Allah SWT.

\section{Analisi Hukum Islam Terhadap Perjanjian Iklan di Radio SAS FM}

Hukum Islam adalah suatu norma yang diperuntukan untuk semua elemen di muka bumi ini khususnya manusia. Adapun perubahan suatu hukum dikarenakan adanya ijtihad para ulama kontemporer berdasarkan situasi, kondisi, dan perkembangan zaman yang kian menimbulkan pengkajian secara mendalam.

Dalam pembahasan kali ini, penulis ingin mendalami hukum Islam yang berkaitan dengan perjanjian. Pada bab sebelumnya dijelaskan adanya wanprestasi berupa tidak sesuainya jam tayang iklan dengan kesepakatan Mou. Perjanjian dalam hukum Islam sering disebut dengan akad yaitu suatu kesepatakan transaksi yang terbingkai dengan nilai-nilai syariah. Dalam akad juga terdapat yang namanya ijab qabul sesuai dengan kehendak syariat yang nantinya akan berpengaruh pada objek perikatan. Dalam hal ini, pihak radio SAS FM dan juga client telah melakukan sebuah perjanjian, yaitu perjanjian penayangan iklan YDSF dan UNUSA. Dari

\footnotetext{
${ }^{28}$ Asmuni Rahmad A, Ilmu Fiqih 3 (Jakarta: Direktorat Pemberdayaan Wakaf direktorat Jendral Bimbingan Masyarakat Islam, 2007). 120

${ }^{29}$ Musyaf Aisyah Al-Qur'an Dan Terjemah.285
} 
pemaparan di atas dapat disimpulkan bahwa pengertian akad mencakup: ${ }^{30}$

1. Perjanjian atau Al-Ahd; dalam hal ini pihak SAS FM melakukan perjanjian iklan yang dibuktikan dengan adanya MoU dengan para pengiklan atau client.

2. Persetujuan dua orang atau lebih; telah disetujuan antara pihak SAS FM dan juga pengiklan atau client mengenai penayangan iklan baik berupa jenis iklan, waktu, dan pembayarannya.

3. Perikatan atau $A l-A q d$; perikatan ini ada sebab perjanjian yang ditimbulkan antara pihak SAS FM dan pengiklan atau client.

Menurut Abdul Aziz Muhammad Azzam dalam buku yang berjudul Fiqh Muamalat, ${ }^{31}$ setiap yang diikatkan oleh seseorang terhadap suatu urusan yang akan dilaksanakan secara wajib atau diikatkan kepada orang lain untuk dilaksanakan secara wajib, maka maksudnya adalah iltizam atau mengharuskan untuk menunaikan janjia yang telah disepakati oleh kedua belah pihak. Berari dalam hal ini, kedua belah pihak adalah Radio SAS FM dan juga client yang diharuskan untuk saling memenuhi kesepakatan yang ada. Namun, dalam realita ada beberapa kesepakatan yang tidak dipenuhi yaitu tidak konsistennya penayangan iklan dalam waktu yang telah disepakati sehingga ada kemungkinan pihak client yang dirugikan. Adapun yang menjadi sumber iltizam adalah: 32

1. Akad yaitu kehendak dua belah pihak untuk melakukan sebuah perikatan, dalam hal ini telah dilakukan pengiklan atau client yang dengan suka rela memilih SAS FM sebagai media partner dalam penayangan iklan.

2. Kehendak sepihak, keinginan sendiri untuk melakukan sesuatu, dalam hal ini pihak client menginginkan secara

\footnotetext{
${ }^{30}$ Huda, Fiqh Muamalah.26

${ }^{31}$ Azzam, Fiqh Muamalat.16

${ }^{32}$ Dewi, Hukum Perikatan Islam Di Indonesia. 82
} 
sepihak untuk menentukan penayangan jenis iklan yang akan ditayangkan di radio SAS FM.

3. Perbuatan yang bermnfaat, sperti menolong orang yang membutuhkan pertolongan, adapun dalam kasus ini radio SAS FM memberikan jasa atau menolong pengiklan untuk mempromosikan melalui udara mengenai hal yang perlu dipromosikan.

4. Perbuatan yang merugikan seperti ketika merusak milik orang lain, yang merusak wajib mengganti, dalam kasus ini pihak yang dirugikan adalah client dengan tidak ditayangkan iklan sebagaimana kesepakatan, jadi pihak SAS FM diwajibkan untuk mengganti jam tayang di luar kesepakatan yang sudah ada.

\section{Penutup}

Peneliti menarik kesimpulan bahwa mekanisme perjanjian iklan di radio SAS FM Surabaya dengan pengiklan yakni Yayasan Dana Sosial Al Falah atau YDSF secara prosedur tidak ada masalah, namun secara praktik terdapat adanya wanprestasi atau ingkar janji yang dilakukan oleh radio SAS FM dengan sebab adanya kelalaian penyiar untuk memanagemen waktu sehingga iklan tersebut tidak dapat diputar sebagaimana kesepakatan yakni tepat pada time signal radio SAS FM Surabaya, selain itu adanya pemadaman listrik yang tidak menentu, serta terjadi rusaknya pemancar pada waktu yang tidak bisa diduga. Perjanjian Iklan radio SAS FM Surabaya menurut hukum Islam terdapat syarat-syarat yang tidak dipenuhi dan menyebabkan kerugian pada salah satu pihak yaitu pihak pengiklan YDSF yang mana tidak diputarnya iklan tepat pada time signal. Adapun menurut hukum positif juga menimbulkan kerugian kepada pihak yang melangsung iklan, sehingga pihak pengiklan dapat menuntut yang namanya ganti rugi baik berupa materi ataupun kerugian biaya. Tujuan dari penelitian ini adalah supaya kita dapat menegtahui penyebab timbulnya suatu kecacatan akad atau perjanjian menurutv pandangan hukum Islam dan hukum positif. Hasil menunjukan bahwa di dalam sebuah perjanjian atau akad antara hukum Islam dan hukum positif terdapat suatu kesamaan. Sehingga 
pihak Iklan radio SAS FM Surabaya memberi ganti rugi berupa waktu siar ulang kembali kepada pihak pengiklan YDSF.

Mekanisme perjanjian iklan di radio SAS FM Surabaya dengan pengiklan yakni Yayasan Dana Sosial Al Falah atau YDSF secara prosedur tidak ada masalah, namun secara praktik terdapat adanya wanprestasi atau ingkar janji yang dilakukan oleh radio SAS FM dengan sebab adanya kelalaian penyiar untuk memanagemen waktu sehingga iklan tersebut tidak dapat diputar sebagaimana kesepakatan yakni tepat pada time signal radio SAS FM Surabaya, selain itu adanya pemadaman listrik yang tidak menentu, serta terjadi rusaknya pemancar pada waktu yang tidak bisa diduga. Perjanjian Iklan radio SAS FM Surabaya menurut hukum Islam terdapat syarat-syarat yang tidak dipenuhi dan menyebabkan kerugian pada salah satu pihak yaitu pihak pengiklan YDSF yang mana tidak diputarnya iklan tepat pada time signal. Adapun menurut hukum positif juga menimbulkan kerugian kepada pihak yang melangsung iklan, sehingga pihak pengiklan dapat menuntut yang namanya ganti rugi baik berupa materi ataupun kerugian biaya.

\section{Daftar Pustaka}

Anwar, Syamsul. Hukum Perjanjian Syariah. Jakarta: Rajawali Pers, 2010.

Ascarya. Akad Dan Produk Bank Syariah. Jakarta: RajaGrafindo Persada, 2011.

Azzam, Abdullah Aziz Muhammad. Fiqh Muamalat. Jakarta:

Sinar Grafika Offset, 2010.

Basyir, Ahmad Azar. Asas-Asas Hukum Muamalat. Yogyakarta:

Universitas Islam Indonesia Press, 2000.

Dewi, Gemala. Dkk. Hukum Perikatan Islam Di Indonesia, n.d.

Dewi, Gemala. Aspek-Aspek Hukum Dan Perasuransian Syari'ah

Di Indonesia. Jakarta: Kencana Cet ke-4, 2007.

Harun, Nasrun. Fiqh Muamalat. Jakarta: Gaya Media Pratama, 2000.

Huda, Qomarul. Fiqh Muamalah. Yogyakarta: Teras, 2011. Ibrahin, Johannes. Kartu Kredit Dilematis Antara Kontrak Dan Kejahatan. Bandung: PT Refika Aditama, 2004. 
Kiswono. Gugup. Pengantar Bisnis. Edisi 1, C. Yogyakarta: BPFE, 2001.

Muhammad, Abdul Kadir. Hukum Perikatan. Bandung: Bina Cipta, 1982.

-—- Hukum Perjanjian. Bandung: Alumni, 1980.

Munawwir, A.W. Kamus Al-Munawwir Arab-Indonesia Lengkap. Surabaya: Pustaka Progressif, 1997.

Rahmad A, Asmuni. Ilmu Fiqih 3. Jakarta: Direktorat

Pemberdayaan Wakaf direktorat Jendral Bimbingan

Masyarakat Islam, 2007.

Sistaningrum. Manajemen Promosi Pemasaran. Jakarta: Index, 2002.

Subekti. Hukum Perjanjian. Jakarta: Intermesa cet ke-12, 1990. Suryanto, M. Marketing Strategi. Yogyakarta: Andi Publisher, 2007.

Swastha.Dkk. Asas-Asas Marketing. Yogyakarta: Liberty, 2005. Tutik, Titik Triwulan. Hukum Perdata Dalam Sistem Hukum Nasional. Jakarta: Kencana, 2008.

Ya'qub, Fayruz Abadyy Majd al-Din Muhammad Ibn. Al-Qamus Al-Muhit. Jilid 1. Beirut: D Jayl, n.d.

Yunus, Mahmud. Kamus Arab Indonesia. Jakarta: PT. Mahmud Yunus, n.d.

Kitab Undang-Undang Perdata. Jakarta: PT. Pradnya Paramita, n.d.

Musyaf Aisyah Al-Qur'an Dan Terjemah. Bandung: Jabal, n.d.

"Pengertian ,Fungsi Tujuan Promosi."

https://dhanialfirdaus.wordpress.com/2008/11/06/defin isipengertian-promosi-fungsitujuan-bauran-promosipromotional-mix-produk/. 